\title{
Aryl- and Alkenyllithium Preparations and Copper-catalyzed Reaction between the Derived Magnesium Reagents and Monoacetate of 4-Cyclopentene-1,3-diol
}

\author{
Kenya Nakata and Yuichi Kobayashi* \\ Department of Biomolecular Engineering, Tokyo Institute of Technology \\ Box B-52, 4259 Nagatsuta-cho, Midori-ku, Yokohama 226-8501 \\ Japan \\ ykobayas@bio.titech.ac.jp \\ HO». $\Longrightarrow$.OAC $\frac{\mathrm{RLi} / \mathrm{MgCl}_{2}}{\text { CuCN cat. }}$

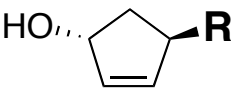 \\ $\mathrm{R}=$ aryl, alkenyl
}

Compatibility of the Preparations of RLi

$\begin{array}{llll}\bigcirc & \mathrm{Ar}-\mathrm{X}+\mathrm{Li} & & \mathrm{Ar}-\mathrm{SnBu} u_{3}+n \text {-BuLi } \\ \square & \mathrm{Ar}-\mathrm{X}+n \text {-BuLi } & \bigcirc & \mathrm{Ar}-\mathrm{H}+n \text {-BuLi } \\ \bigcirc & \mathrm{Ar}-\mathrm{X}+t \text {-BuLi } & & \end{array}$

Typical procedures: $\quad$ p. $2-4$

${ }^{1} \mathrm{H}$ NMR spectra of $\mathbf{2 a}, \mathbf{2 b}, \mathbf{2 c}, \mathbf{2 d}, \mathbf{2 e}, \mathbf{2 \mathbf { f }}$, and ${ }^{13} \mathrm{C}$ NMR spectrum of $\mathbf{2 b}: \quad$ p. $5-11$ 


\section{General:}

Identity and purity of the products $\mathbf{2 a}, \mathbf{2 c}-\mathbf{f}$ were confirmed by comparison with the spectral data reported (Kobayashi, Y.; Murugesh, M. G.; Nakano, M.; Takahisa, E.; Usmani, S. B.; Ainai, T., J. Org. Chem., 2002, 67, 7110-7123), and those for $\mathbf{2 b}$ were established by ${ }^{1} \mathrm{H}$ NMR and ${ }^{13} \mathrm{C}$ NMR spectra.

\section{Phenylation with PhMgCl Derived from Pure PhLi:}

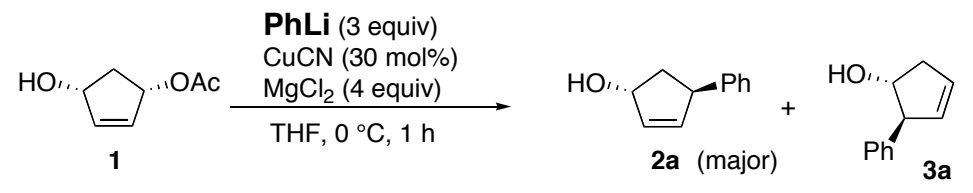

To a mixture of $\mathrm{Mg}(29.2 \mathrm{mg}, 1.20 \mathrm{mmol})$ and THF (0.5 mL) was added 1,2-dichloroethane $(0.28 \mathrm{~mL}, 3.55 \mathrm{mmol})$ at room temperature under argon atmosphere. After being stirred at room temperature for $30 \mathrm{~min}$, the mixture was diluted with THF $(0.5 \mathrm{~mL})$ and was stirred at the same temperature for $30 \mathrm{~min}$ to dissolve $\mathrm{Mg}$ completely. The resulting suspension was diluted with THF $(1.5 \mathrm{~mL})$ to preparer a clear solution and cooled to $0{ }^{\circ} \mathrm{C}$. To the mixture were added $\mathrm{PhLi}$ (0.96 mL, $0.94 \mathrm{M}$ in cyclohexane-Et $\left.{ }_{2} \mathrm{O}(2: 1), 0.90 \mathrm{mmol}\right), \mathrm{CuCN}(8.1$ $\mathrm{mg}, 0.09 \mathrm{mmol})$, and a solution of monoacetate $1(42.3 \mathrm{mg}, 0.30 \mathrm{mmol})$ in THF (1 mL), each after $15 \mathrm{~min}$ interval. The mixture was stirred for $1 \mathrm{~h}$ at the same temperature and then diluted with saturated $\mathrm{NH}_{4} \mathrm{Cl}$ to quench the reaction. After extraction with EtOAc four times, combined extracts were dried over $\mathrm{MgSO}_{4}$ and concentrated under reduced pressure. The residue was purified by silica gel chromatography (hexane/EtOAc $=4: 1$ to $1: 1$ ) to afford 4-phenyl-2-cyclopenten-1-ol (2a) (35.6 mg, 75\%). The ${ }^{1} \mathrm{H}$ NMR spectrum of $2 \mathbf{a}$ thus synthesized was identical with that previously reported (Tueting, D. R.; Echavarren, A. M., Stille, J. K. Tetrahedron 1989, 45, 979-992) and a copy of the spectrum was attached to this supporting information.

\section{Lithiation of Iodobenzene by $t$-BuLi and Subsequent Phenylation with the Derived PhMgCl:}




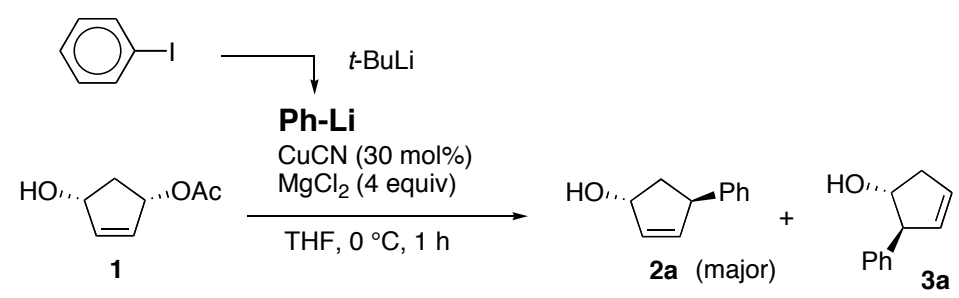

To a solution of PhI $(0.101 \mathrm{~mL}, 0.90 \mathrm{mmol})$ in THF $(1 \mathrm{~mL})$ was added $t$-BuLi $(1.26 \mathrm{~mL}$, $1.43 \mathrm{M}$ in pentane, $1.80 \mathrm{mmol}$ ) slowly at $-78{ }^{\circ} \mathrm{C}$. After $30 \mathrm{~min}$ at $-78{ }^{\circ} \mathrm{C}$, a solution of $\mathrm{MgCl}_{2}(2.50 \mathrm{~mL}, 0.48 \mathrm{M}$ in THF, $1.20 \mathrm{mmol}$ ) was added to the solution dropwise. The cooling bath $\left(-78{ }^{\circ} \mathrm{C}\right)$ was changed to an ice-water bath, and stirring was continued for 20 min. To the resulting solution were added $\mathrm{CuCN}(8.1 \mathrm{mg}, 0.09 \mathrm{mmol})$ and, after $15 \mathrm{~min}, 1$ (42.6 mg, $0.30 \mathrm{mmol})$ in THF $(1 \mathrm{~mL})$. The whole mixture was stirred at the same temperature for $1 \mathrm{~h}$, and diluted with saturated $\mathrm{NH}_{4} \mathrm{Cl}$ with vigorous stirring. The products were extracted with EtOAc four times, and the combined layers were dried over $\mathrm{MgSO}_{4}$. After concentration under reduced pressure, the residue was subjected to silica gel chromatography (hexane/EtOAc $=9: 1$ to $4: 1)$ to give $\mathbf{2 a}(43.7 \mathrm{mg}, 91 \%)$.

\section{Lithiation of Tributylstannylbenzene by $n$-BuLi and Subsequent Phenylation with the Derived PhMgCl:}

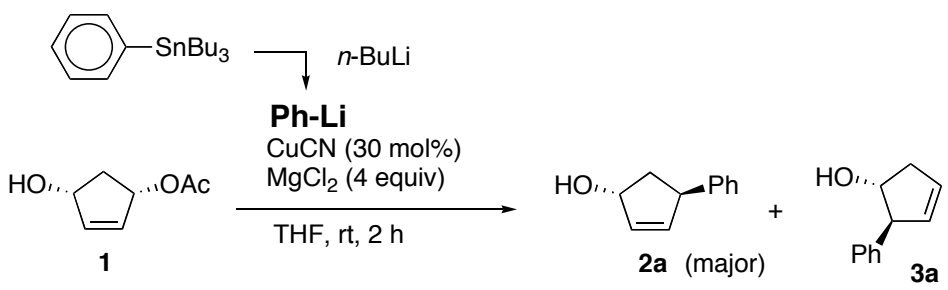

To an ice-cold solution of $\mathrm{PhSnBu}_{3}(397 \mathrm{mg}, 1.08 \mathrm{mmol})$ in THF ( $\left.1 \mathrm{~mL}\right)$ was added $n$-BuLi $(0.74 \mathrm{~mL}, 1.45 \mathrm{M}$ in hexane, $1.07 \mathrm{mmol})$ slowly, and the solution was stirred for $30 \mathrm{~min}$ at $0{ }^{\circ} \mathrm{C}$. To the solution were added $\mathrm{MgCl}_{2}$ (2.50 mL, $0.48 \mathrm{M}$ in THF, $\left.1.20 \mathrm{mmol}\right), \mathrm{CuCN}$ (8.1 $\mathrm{mg}, 0.09 \mathrm{mmol})$, and a solution of $1(42.6 \mathrm{mg}, 0.30 \mathrm{mmol})$ in THF (1 mL), each after 15 min interval. The resulting mixture was stirred at room temperature for $2 \mathrm{~h}$, and diluted with saturated $\mathrm{NH}_{4} \mathrm{Cl}$ with vigorous stirring. The products were extracted with EtOAc four times, and the combined layers were dried over $\mathrm{MgSO}_{4}$. After concentration under reduced pressure, the residue was subjected to silica gel chromatography (hexane/EtOAc $=4: 1$ to 
$1: 1)$ to give $\mathbf{2 a}(35.6 \mathrm{mg}, 74 \%)$.

Direct Lithiation of Methoxymethylbenzene by $\boldsymbol{n}$-BuLi and Subsequent Reaction with the Derived Magnesium Reagent:

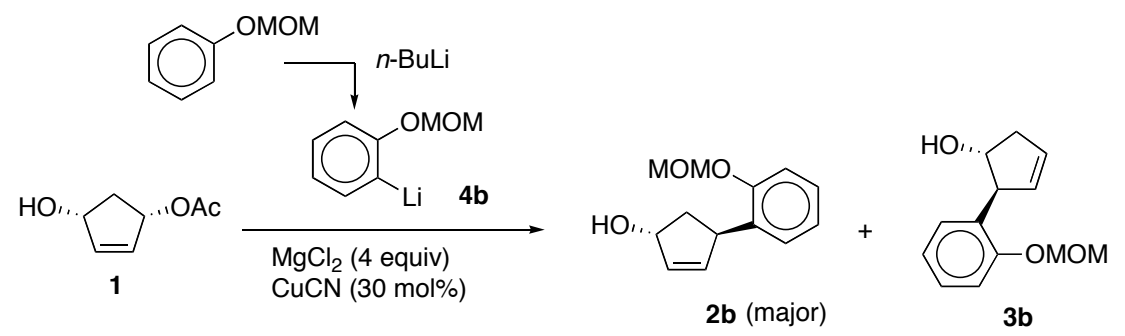

To an ice-cold solution of methoxymethyl phenyl ether (124 mg, $0.90 \mathrm{mmol}$ ) in THF (1 $\mathrm{mL}$ ) was added $n$-BuLi $(0.53 \mathrm{~mL}, 1.71 \mathrm{M}$ in hexane, $0.91 \mathrm{mmol})$ slowly, and the solution was stirred for $30 \mathrm{~min}$. To the solution were added $\mathrm{MgCl}_{2}(2.50 \mathrm{~mL}, 0.48 \mathrm{M}$ in THF, 1.20 $\mathrm{mmol}), \mathrm{CuCN}(8.1 \mathrm{mg}, 0.09 \mathrm{mmol})$, and a solution of 1 (42.6 mg, $0.30 \mathrm{mmol})$ in THF (1 $\mathrm{mL}$ ), each after $15 \mathrm{~min}$ interval. The resulting mixture was stirred at the same temperature for $1 \mathrm{~h}$, and diluted with saturated $\mathrm{NH}_{4} \mathrm{Cl}$ with vigorous stirring. The products were extracted with EtOAc four times. The combined layers were dried over $\mathrm{MgSO}_{4}$ and evaporated under reduced pressure to give an oil, which was purified by silica gel chromatography (hexane/EtOAc $=9: 1$ to $1: 1$ ) to afford $2 \mathbf{b}(54.2 \mathrm{mg}, 82 \%)$ : IR (neat) $3348,1078,755 \mathrm{~cm}^{-1} ;{ }^{1} \mathrm{H}$ NMR (300 MHz, $\mathrm{CDCl}_{3}$ ) $\square 1.68$ (br s, $1 \mathrm{H}$ ), 2.04 (ddd, $J=14,7$, $5.5 \mathrm{~Hz}, 1 \mathrm{H}), 2.32$ (ddd, $J=14,8,3 \mathrm{~Hz}, 1 \mathrm{H}), 3.49(\mathrm{~s}, 3 \mathrm{H}), 4.54(\mathrm{t}, J=6 \mathrm{~Hz}, 1 \mathrm{H}), 5.01(\mathrm{~d}$, $J=6 \mathrm{~Hz}, 1 \mathrm{H}), 5.21(\mathrm{~s}, 2 \mathrm{H}), 6.02-6.08(\mathrm{~m}, 2 \mathrm{H}), 6.93(\mathrm{dt}, J=1,7.5 \mathrm{~Hz}, 1 \mathrm{H}), 7.03(\mathrm{dd}, J=$ $7.5,2 \mathrm{~Hz}, 1 \mathrm{H}), 7.06(\mathrm{dd}, J=8,1 \mathrm{~Hz}, 1 \mathrm{H}), 7.16(\mathrm{dt}, J=2,8 \mathrm{~Hz}, 1 \mathrm{H}) ;{ }^{13} \mathrm{C}$ NMR $(75 \mathrm{MHz}$, $\left.\mathrm{CDCl}_{3}\right) \square 42.7,43.2,56.1,77.5,94.4,113.9,121.8,126.8,127.4,133.8,134.2,138.5$, 154.7 . 


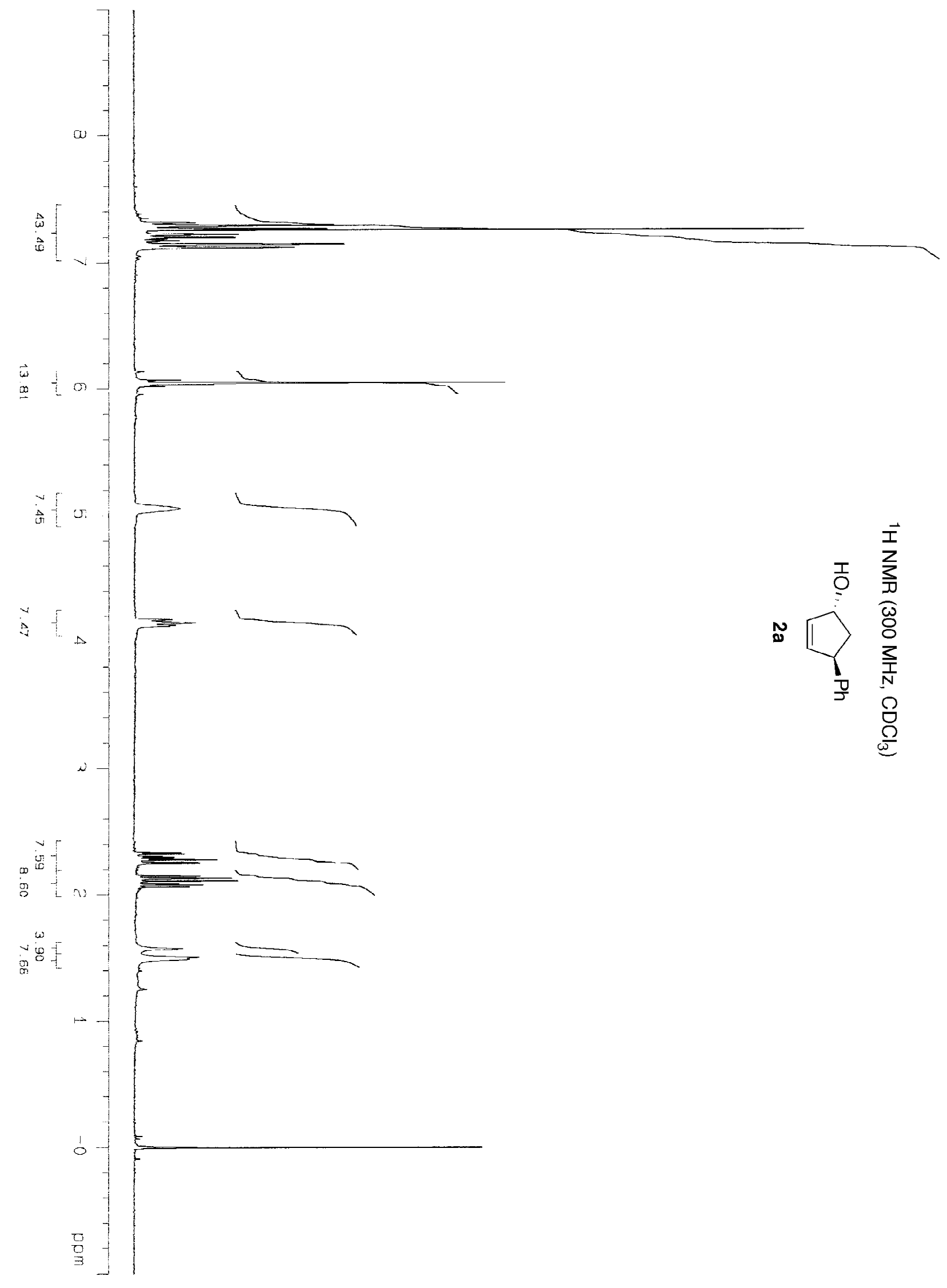




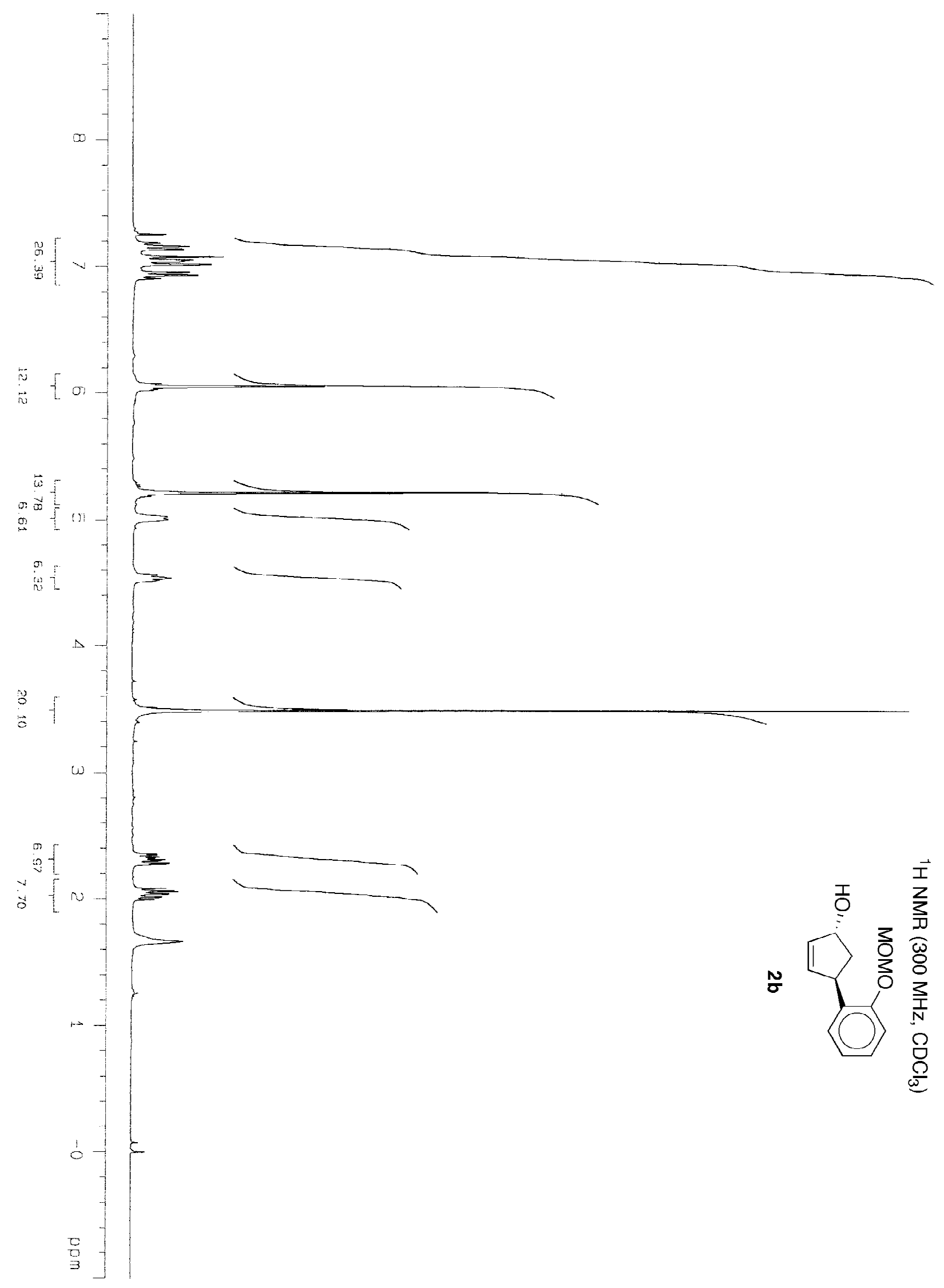



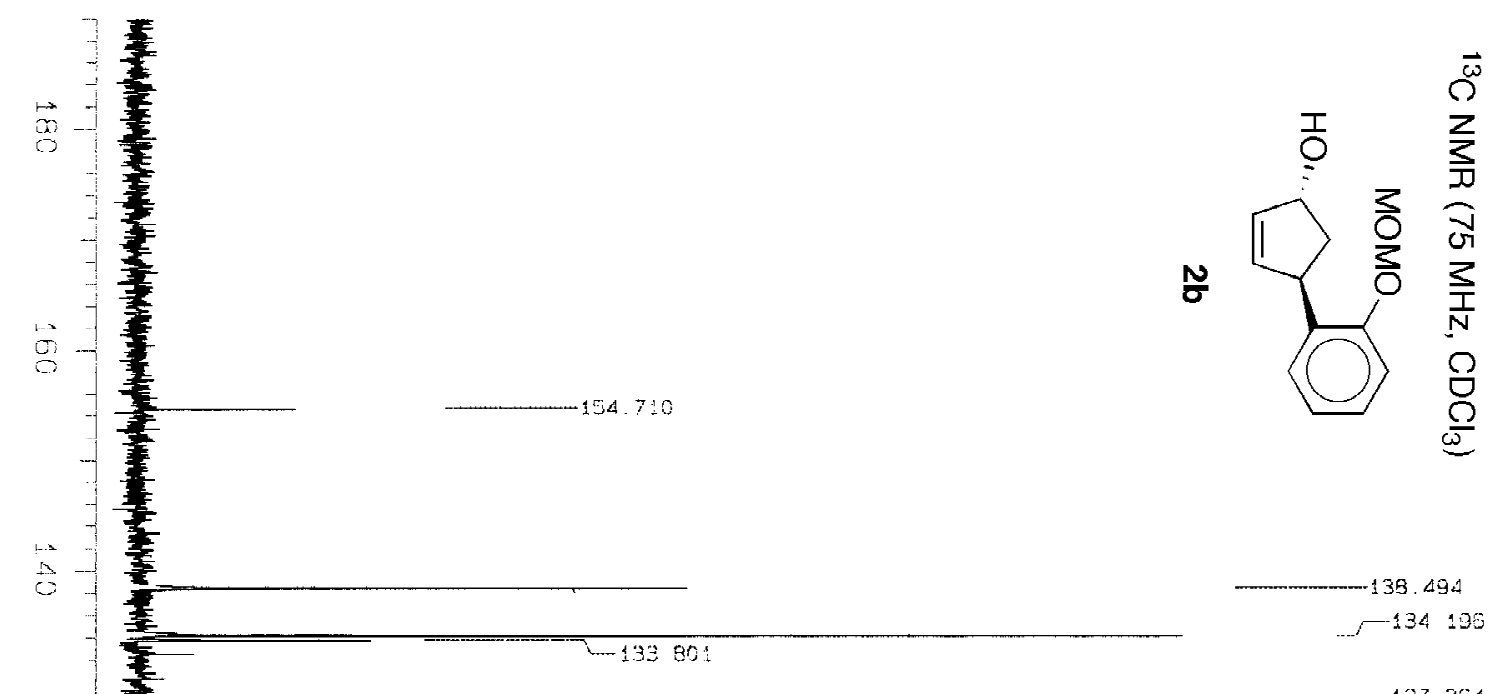

$-139.494$

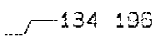

127364

$-125.845$

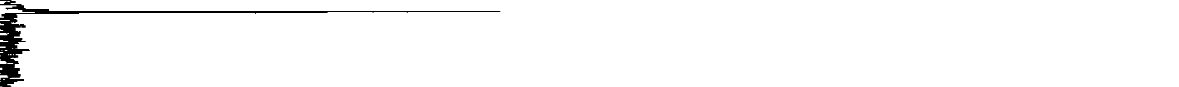

$--113.910$

$.94 \quad 974$

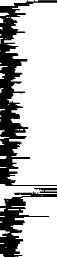

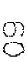

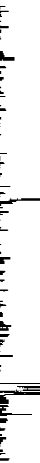

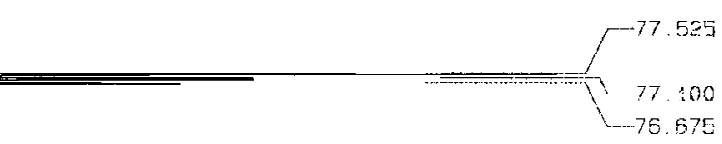

$-77.475$

$56 \quad 033$

$8-1$

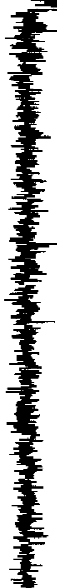

$-43.238$

$-2.4259$ 


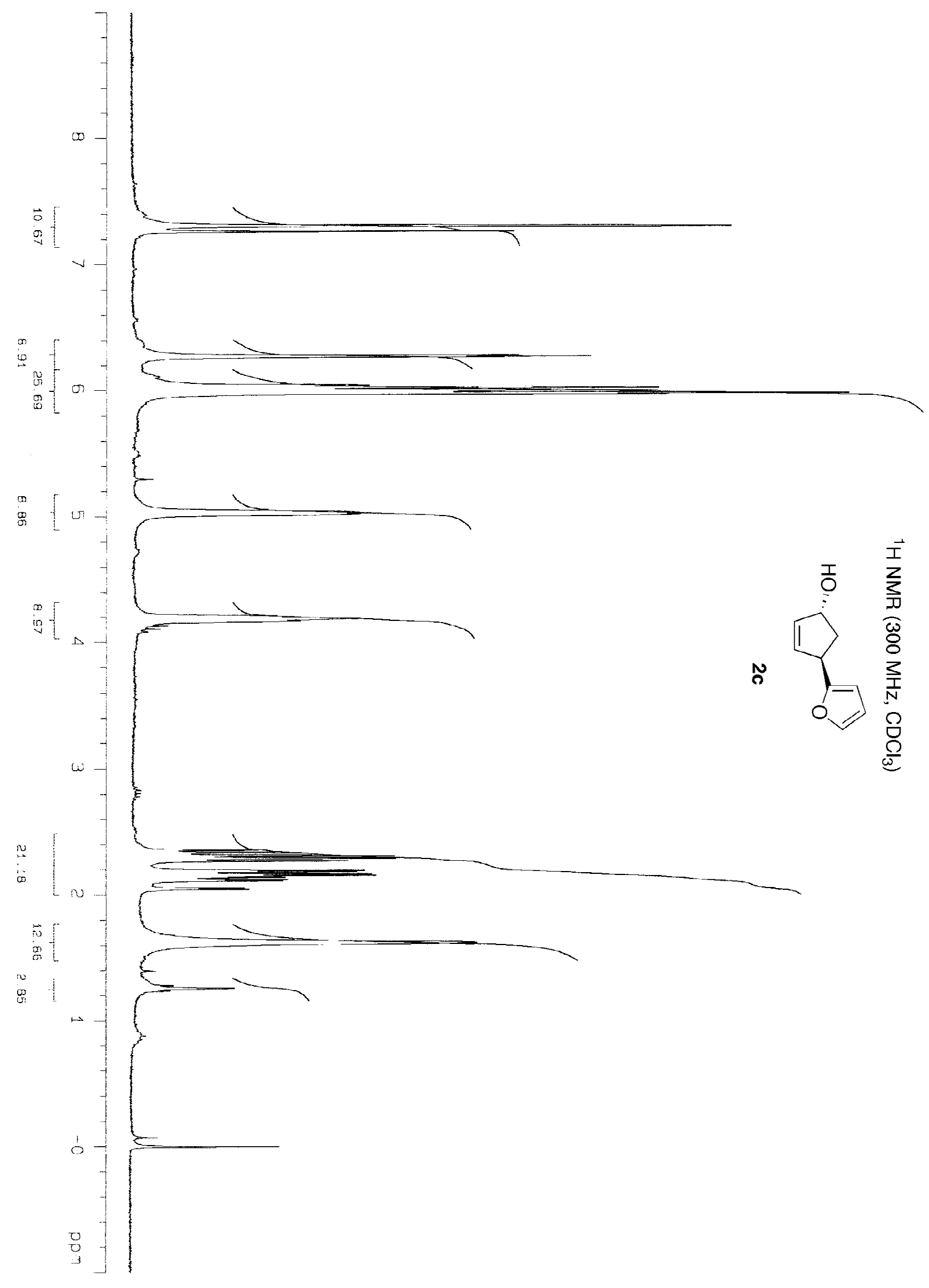




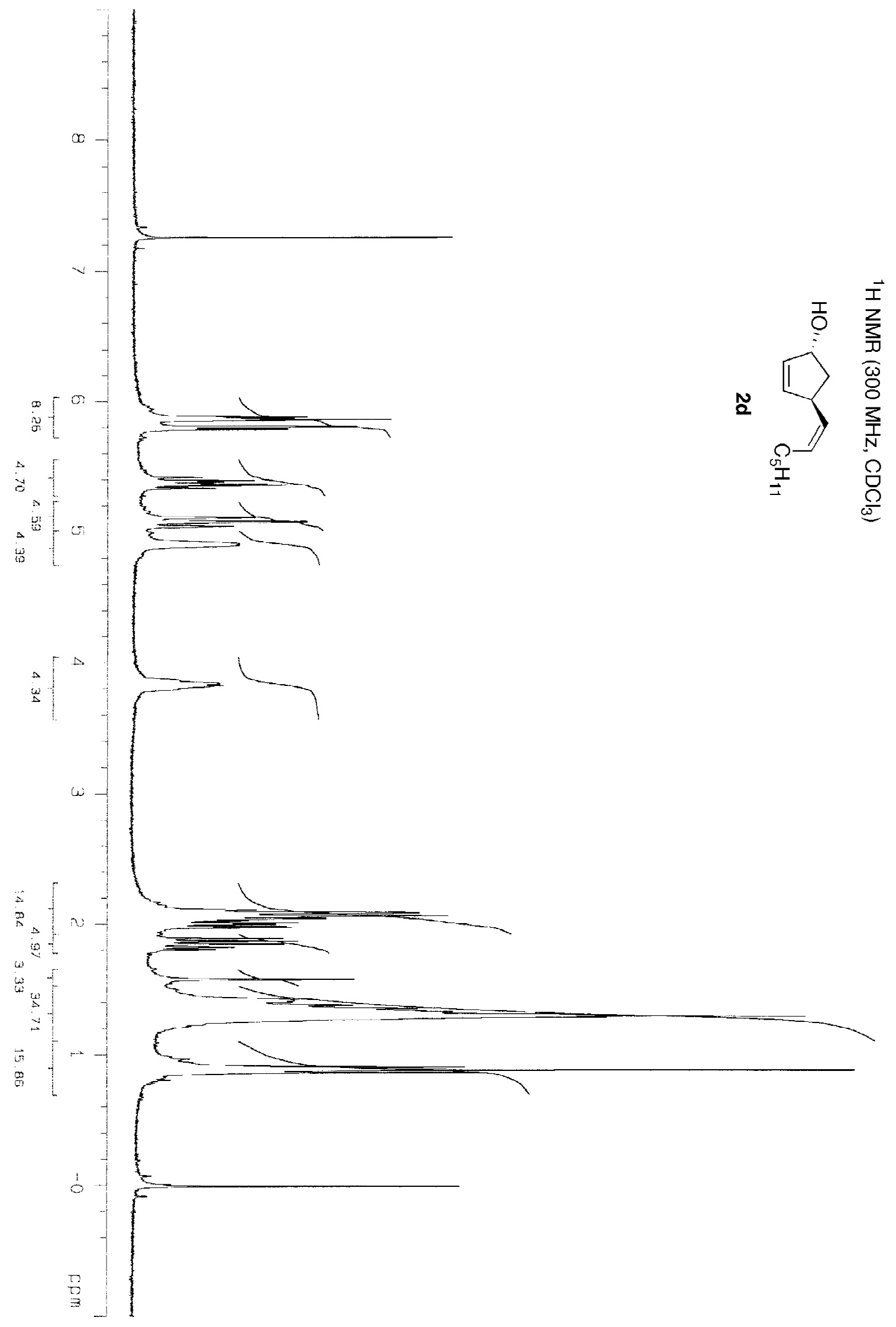




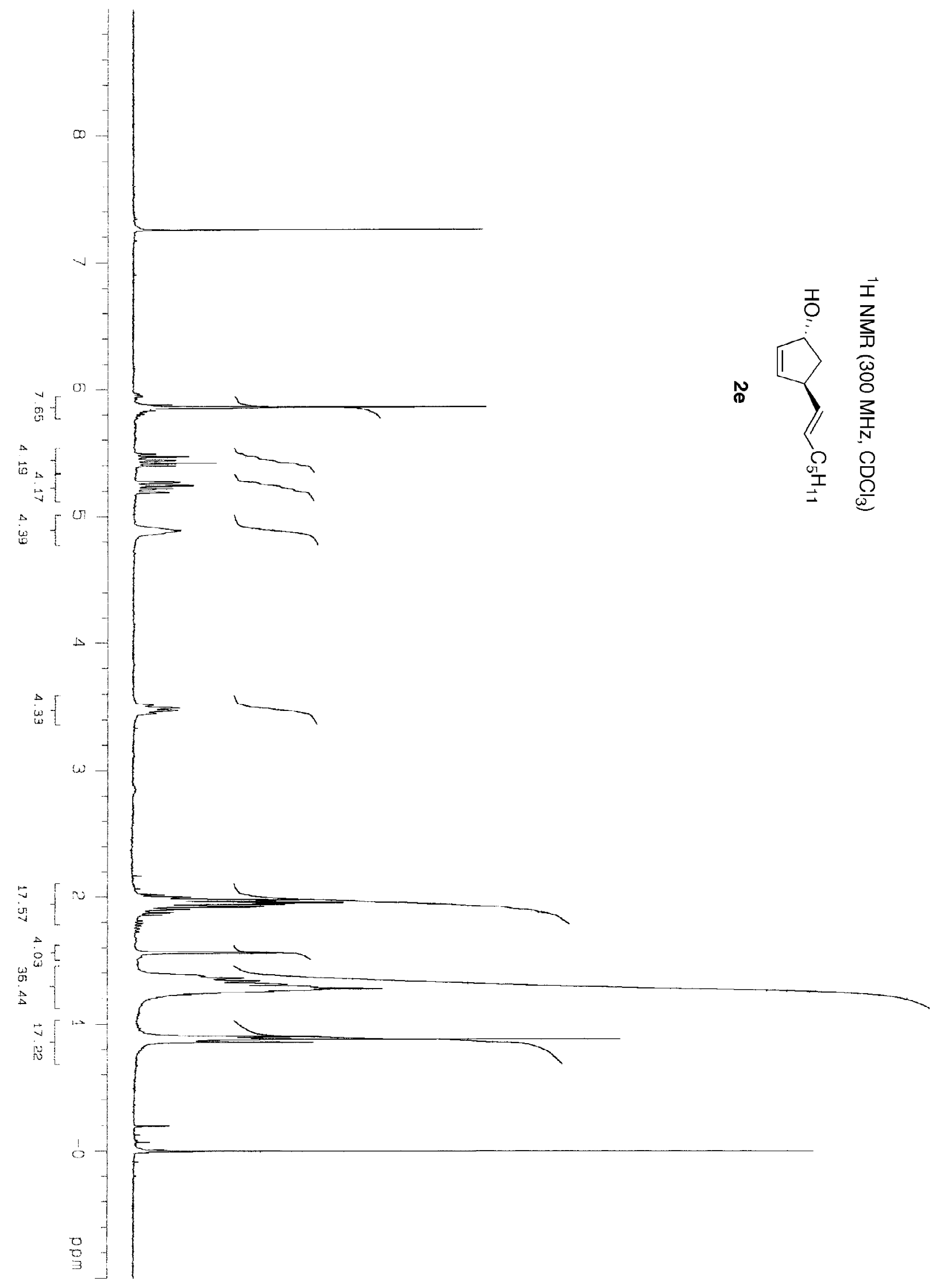




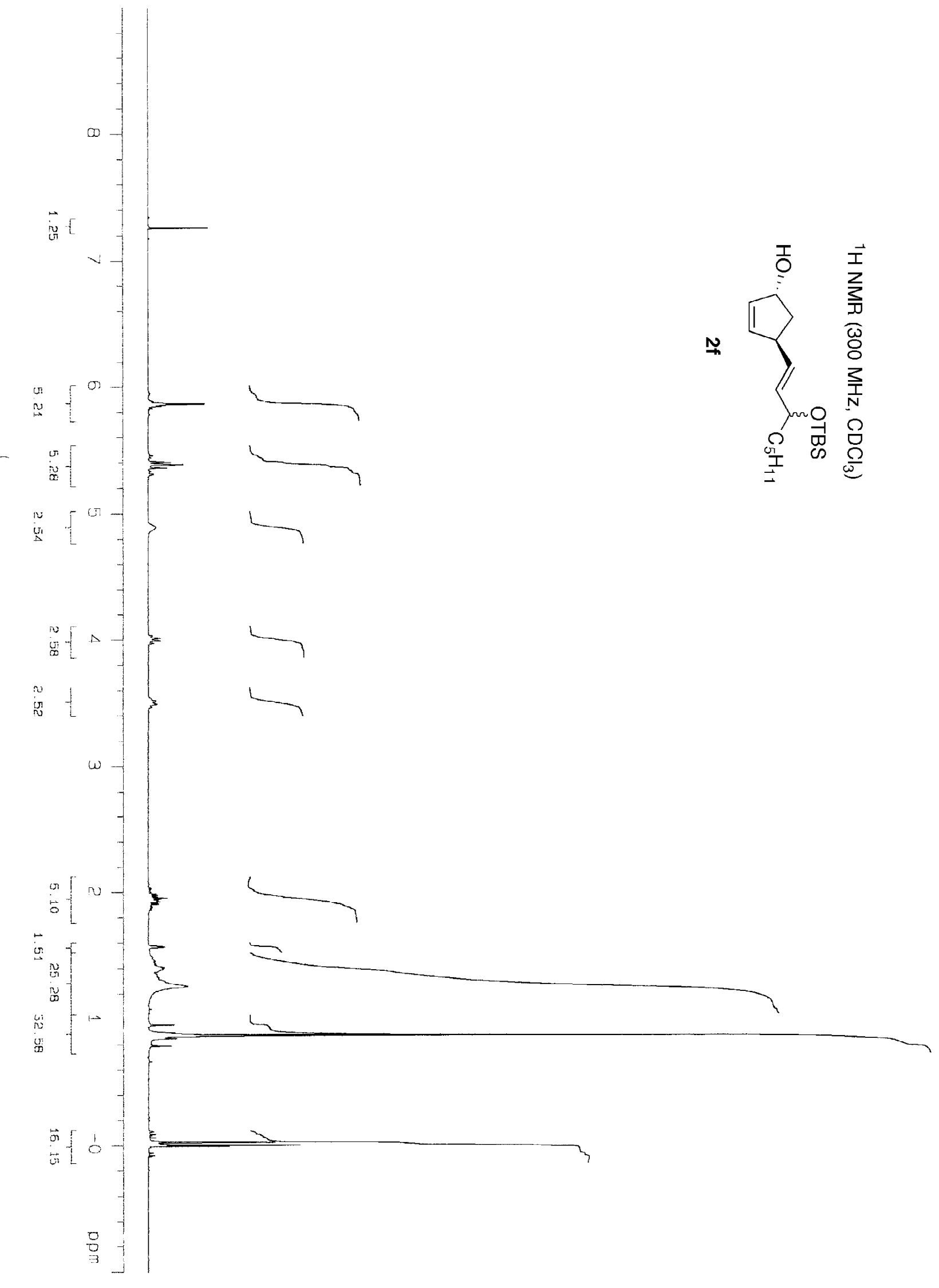

